\title{
GROWTH AND PHYTASE ACTIVITIES OF BACILLUS SUBTILIS IMV B-7023 DURING CULTIVATION WITH SODIUM PHYTATE
}

\author{
N.V. Chuiko, A.Yu. Chobotarov, I.K. Kurdish \\ Zabolotny Institute of Microbiology and Virology, NAS of Ukraine, \\ 154 Acad. Zabolotny Str. Kyiv, 03143, Ukraine \\ e-mail:nelvit@ukr.net
}

Bacteria of the genus Bacillus are known for their ability to mineralize organic phosphorus compounds.
Phytates constitute up to $60-80 \%$ of the total plant phosphorus and almost $50 \%$ of soil organic
phosphorus. Phytates phosphorus is unavailable for plants. Bacillus can synthesize phosphatases both
wide spectrum of action, and highly specific phytases that catalyze the hydrolysis of phytates. Therefore, the aim of this work was to study the growth and phytase activity of Bacillus subtilis IMV B-7023, which is the component of the "Azogran" complex bacterial preparation for plant growing. Methods. The growth activity of bacteria was studied by cultivation methods, the phytase activity - by measuring the amount of phosphate released from sodium phytate during the enzymatic reaction. Results. It was shown that B. subtilis IMV B-7023 assimilated phytate as the source of phosphorus nutrition during cultivation in media with 0.5, 1.0 and $2.0 \mathrm{~g} / \mathrm{L}$ of sodium phytate. The highest growth activity of these bacteria was observed after two days of cultivation in medium with $1.0 \mathrm{~g} / \mathrm{L}$ of phytate. The number of bacteria was $(3.91 \pm 0.32) \times 10^{9} \mathrm{CFU} / \mathrm{mL}$ under these conditions. At the same time, B. subtilis IMV B-7023 demonstrated a low level of phytate assimilation as a source of carbon nutrition. Thus, after two days of cultivation the number of bacteria increased from $(4.12 \pm 0.09) \times 10^{6} \mathrm{CFU} / \mathrm{mL}$ to $(1.07 \pm 0.07-3.11 \pm 0.51) \times 10^{7} \mathrm{CFU} / \mathrm{mL}$ in the presence of $0.5-2.0 \mathrm{~g} / \mathrm{L}$ phytate in the medium and the absence of another carbon source. It was determined that strain B. subtilis IMV B-7023 had phytase activity, the highest activity $(221.85 \pm 0.12 \mathrm{U} / \mathrm{g})$ was on the first day of their cultivation in medium with inorganic phosphates. It should be noted that B. subtilis IMV B-7023 phytase activity was lower during cultivating in medium with sodium phytate as a source of phosphorus nutrition, than in medium with inorganic phosphates. The obtained fact may be due to phytate hydrolysis by widespecific phosphatases. Higher rates of phytase activity obtained on the first and third days compared to the second and fourth days of bacterial cultivation may indicate the expression of phosphatases genes only in the period required for maximum bacterial development, in the absence of these proteins in the media. At the same time, the phytase activity of B. subtilis IMV B-7023 after 2 days cultivation in a media with 0.5 and $1.0 \mathrm{~g} / \mathrm{L}$ of sodium phytate $(194.80 \pm 0.15 \mathrm{U} / \mathrm{g}$ and $160.90 \pm 0.13 \mathrm{U} / \mathrm{g}$, respectively) as the source of carbon and phosphorus was higher compared to the activity of bacteria on medium with inorganic phosphates $(137.79 \pm 0.10 \mathrm{U} / \mathrm{g})$. This may be caused by the synthesis of a larger number of highly specific phosphatases (phytases) in bacterial cells at the presence of only phytate in the medium as a substrate. Conclusions. B. subtilis IMV B-7023 strain is characterized by growth on nutrient medium with sodium phytate and phytase activity. Because they are soil microorganisms used as the component of the "Azogran" complex bacterial preparation for plant growing, the ability to hydrolyze and assimilate phytate is important for functioning of this strain in the rhizosphere. The obtained results extend the understanding of B. subtilis IMV B-7023 influence on phosphorus nutrition and development of plants.

Keywords: Bacillus subtilis IMV B-7023, phytate, growth activity, phytase activity.

Bacteria of the genus Bacillus are known for their ability to solubilize phosphorus from hard soluble inorganic phosphates and to mineralize organic phosphorus compounds. Such properties are caused by bacterial synthesis of organic acids and phosphatases both wide spectrum of action, and highly specific, which activity is directed on certain substrates $[1,2]$. Phytases (myoinositol hexakisphosphate phosphohydrolases) are one of these phosphatases [3]. These enzymes catalyze the phytic acid or its salts (phytates) hydrolysis to form lower inositol phosphates (which contain less than six phosphate groups), inositol, inorganic phosphate, and release phytate-related cations [4]. 
It is known that phytates constitute up to $60-80 \%$ of the total plant phosphorus [5]. These substances can also constitute almost $50 \%$ of soil organic phosphorus, depending on soil types and its use [6]. At the same time, phytates phosphorus is unavailable for plants, and available phosphorus deficiency is one of the main problems of agricultural production. Therefore, the role of bacterial phytases is extremely important for phosphorus providing of plants. In view of the above, the aim of this work was to study the growth and phytase activity of bacteria Bacillus subtilis IMV B-7023, which are the component of the "Azogran" complex bacterial preparation for plant growing.

Materials and methods. Strain B. subtilis IMV B-7023 was the object of research [7]. These bacteria were isolated from the soil by the employees of the department of microbiological processes on solid surfaces of D.K. Zabolotny Institute of Microbiology and Virology NAS of Ukraine [8]. Strain B. subtilis IMV B-7023 was cultivated in liquid Menkina's medium of the next composition ( $\mathrm{g} / \mathrm{L}$ of distilled water): $\mathrm{K}_{2} \mathrm{HPO}_{4}-$ $0.5 ; \mathrm{KH}_{2} \mathrm{PO}_{4}-0.5 ;\left(\mathrm{NH}_{4}\right)_{2} \mathrm{SO}_{4}-0.5 ; \mathrm{MgSO}_{4} \cdot 7 \mathrm{H}_{2} \mathrm{O}$ $-0.3 ; \mathrm{NaCl}-0.3 ; \mathrm{KCl}-0.3 ; \mathrm{MnSO}_{4} \cdot 5 \mathrm{H}_{2} \mathrm{O}$ and $\mathrm{FeSO}_{4}-0.001$ each; $\mathrm{CaCO}_{3}-2.0$; glucose -10.0 ; $\mathrm{pH}$ 7.2. The study of sodium phytate different concentrations effect on B. subtilis IMV B-7023 growth was performed in the modified Menkina's medium prepared on Tris- $\mathrm{HCl}$ buffer $(\mathrm{pH}$ 7.2). When phytate was used as a phosphorus source, inorganic phosphate was replaced by sodium phytate $(0.5,1.0,2.0 \mathrm{~g} / \mathrm{L}$ in different variants). The modified medium did not contain glucose for the study of phytate as a source of carbon and phosphorus. Cultivation temperature was $28^{\circ} \mathrm{C}$.

For determination of B. subtilis IMV B-7023 extracellular phytase activity bacteria were precipitated by centrifugation at $10000 \mathrm{~g}, 4^{\circ} \mathrm{C}$ to get cell-free supernatants. Phytase activity assays were performed by measuring the amount of inorganic phosphate released from sodium phytate during the enzymatic reaction $[9,10]$. The reaction mixture (50 mM Tris- $\mathrm{HCl}$ buffer ( $\mathrm{pH} 7.2), 2 \mathrm{mM}$ sodium phytate and cell-free supernatants) was incubated for $40 \mathrm{~min}$ at $28{ }^{\circ} \mathrm{C}$. This temperature was used because it is optimal for the growth of these bacteria and approximate to their functioning conditions in soils. The reaction was stopped with $10 \%$ trichloroacetic acid. The amount of inorganic phosphate was determined by Fiske-
Subbarow method with ammonium molybdate at wavelength $590 \mathrm{~nm}$. The amount of protein in cell-free supernatants was determined by Bradford assay. One unit of phytase activity was the amount of crude enzyme that catalyzes the sodium phytate hydrolysis with the formation of $1 \mu \mathrm{mol}$ of inorganic phosphate in 1 minute under assay conditions. The results were presented as specific activity, the amount of activity units per gram of cell-free supernatant protein $(\mathrm{U} / \mathrm{g})$.

Data were statistically analyzed using variation statistics methods [11].

Results. It was shown that $B$. subtilis IMV B-7023 assimilated phytate as a source of phosphorus nutrition (Table 1) and grew worse in a culture medium with a low concentration $(0.5 \mathrm{~g} / \mathrm{L})$ of sodium phytate compared to media with 1.0 and $2.0 \mathrm{~g} / \mathrm{L}$ of this substance. The highest growth activity of these bacteria was observed after two days of cultivation in medium with $1.0 \mathrm{~g} / \mathrm{L}$ of sodium phytate. The number of bacteria was $(3.91 \pm 0.32) \times 10^{9} \mathrm{CFU} / \mathrm{mL}$ under these conditions. The growth activity of $B$. subtilis IMV B-7023 in media with sodium phytate in most cases exceeded their growth activity in the control variant in the medium with inorganic phosphates. This could be due to the greater acidification of the culture medium in the control, while in the experimental variants it was more moderate, and, accordingly, created more favorable conditions for bacterial growth (Table 1).

It was determined that strain B. subtilis IMV B-7023 had phytase activity and its maximum in all media variants was observed on the first day of bacterial growth (Fig. 1). Phytase activity decreased after the second day of cultivation also in all studied variants. Phytase activity increased on the third day of bacteria cultivation in Menkina's medium with inorganic phosphates and with 1.0 and $2.0 \mathrm{~g} / \mathrm{L}$ of sodium phytate, and on the fourth day - decreased again. At the same time, the phytase activity of bacteria on medium with $0.5 \mathrm{~g} / \mathrm{L}$ of sodium phytate gradually decreased on the third and fourth days of cultivation. It should be noted that when bacilli were cultivated with phytate as phosphorus source, phytase activity was lower than during cultivation with inorganic phosphates, and ranged from $6.38 \pm 0.18 \mathrm{U} / \mathrm{g}$ to $74.13 \pm 0.10 \mathrm{U} / \mathrm{g}$. The highest $B$. subtilis IMV B-7023 phytase activity $(221.85 \pm 0.12 \mathrm{U} / \mathrm{g})$ was on the first day of their cultivation in Menkina's medium with inorganic phosphates. 


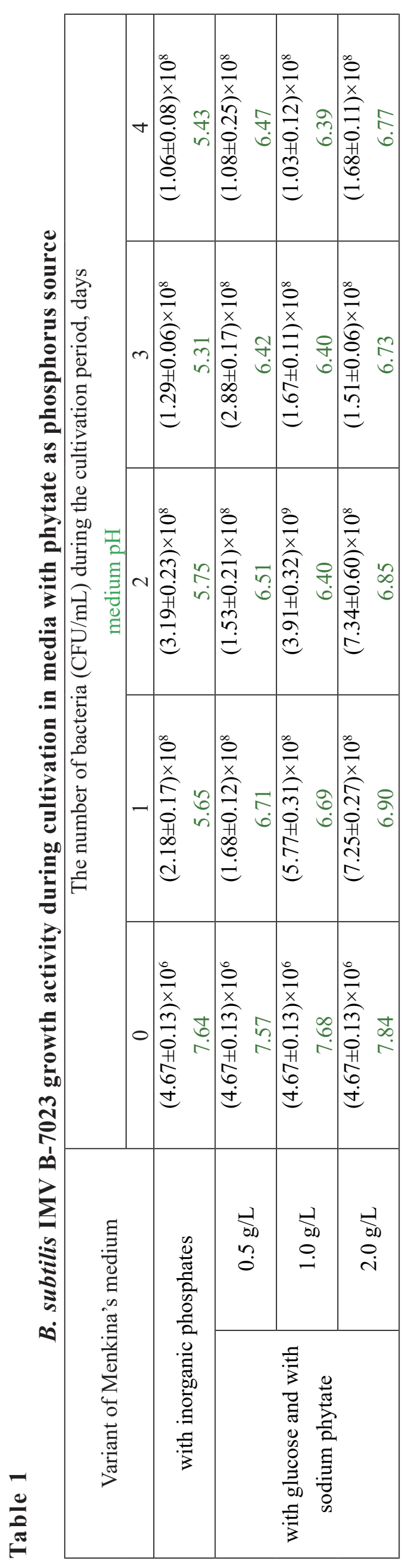

ISSN 1028-0987. Мікробіол. журн., 2021, Т. 83, № 6 


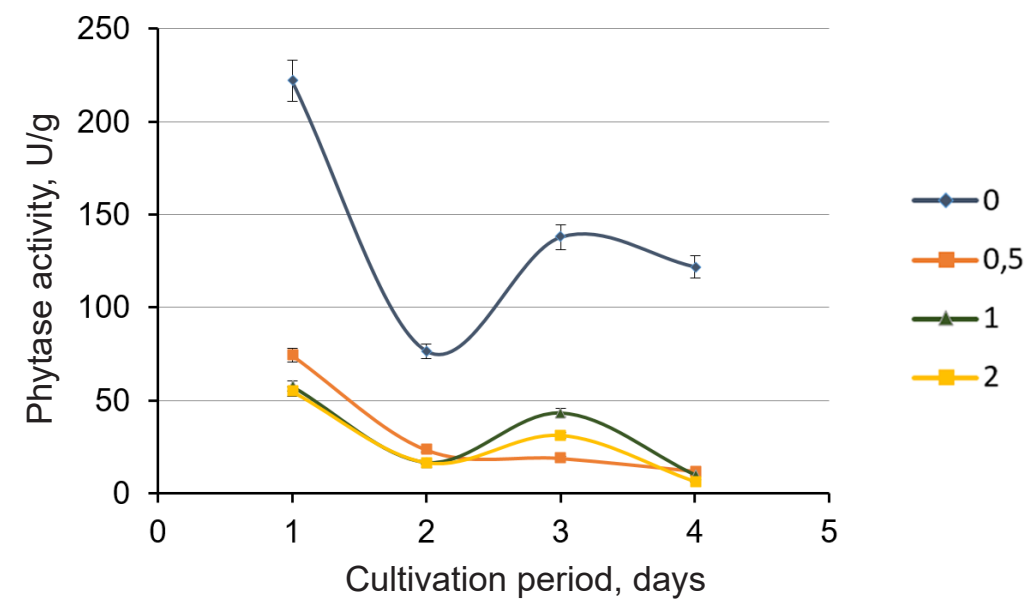

Fig. 1. B. subtilis IMV B-7023 phytase activity during cultivation in Menkina's medium with inorganic phosphates (0) and with sodium phytate as phosphorus source $(0.5,1.0,2.0 \mathrm{~g} / \mathrm{L})$

It was shown that B. subtilis IMV B-7023 grew slightly with phytate as source of carbon and phosphorus nutrition. Thus, with the content in the culture medium of $0.5-2.0 \mathrm{~g} / \mathrm{L}$ phytate, the number of bacteria increased from $(4.12 \pm 0.09) \times$ $10^{6} \mathrm{CFU} / \mathrm{mL}$ to $(1.07 \pm 0.07-3.11 \pm 0.51) \times 10^{7}$ $\mathrm{CFU} / \mathrm{mL}$. At the same time, the number of bacteria was $(7.77 \pm 0.20) \times 10^{8} \mathrm{CFU} / \mathrm{mL}$ at their cultivation during the same period in the medium with inorganic phosphates (Table 2). This study was last only for 2 days, because on media with inorganic phosphates and with sodium phytate as a phosphorus source B. subtilis IMV B-7023 showed maximum growth at this time (Table 1). The phytase activity of B. subtilis IMV B-7023 cultivated for 2 days in a medium with 0.5 and $1.0 \mathrm{~g} / \mathrm{L}$ phytate as the source of carbon and phosphorus was higher compared to the activity of bacteria on Menkina's medium with inorganic phosphates (Fig. 2).

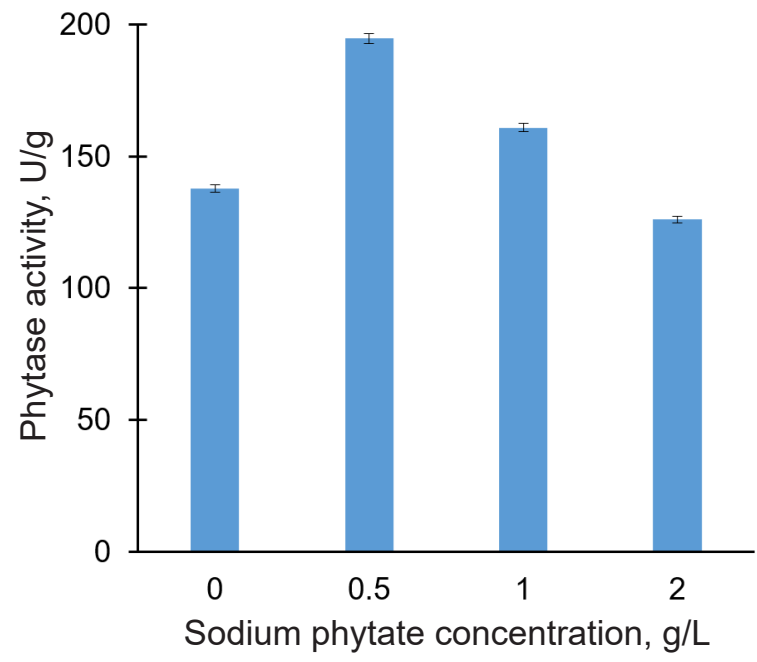

Fig. 2. B. subtilis IMV B-7023 phytase activity during cultivation in Menkina's medium with inorganic phosphates (0) and with sodium phytate as carbon and phosphorus source $(0.5,1.0,2.0 \mathrm{~g} / \mathrm{L})$

Table 2

B. subtilis IMV B-7023 growth activity during cultivation in Menkina's medium with sodium phytate as carbon and phosphorus source

\begin{tabular}{|c|c|c|c|}
\hline \multicolumn{2}{|c|}{ Variant of Menkina's medium } & CFU/mL & $\mathrm{pH}$ \\
\hline \multicolumn{2}{|c|}{ with inorganic phosphates } & $(7.77 \pm 0.20) \times 10^{8}$ & 5.92 \\
\hline \multirow{2}{*}{$\begin{array}{c}\text { without glucose and } \\
\text { with sodium phytate }\end{array}$} & $0.5 \mathrm{~g} / \mathrm{L}$ & $(3.11 \pm 0.51) \times 10^{7}$ & 7.25 \\
\cline { 2 - 4 } & $1.0 \mathrm{~g} / \mathrm{L}$ & $(3.05 \pm 0.48) \times 10^{7}$ & 7.36 \\
\cline { 2 - 4 } & $2.0 \mathrm{~g} / \mathrm{L}$ & $(1.07 \pm 0.07) \times 10^{7}$ & 7.55 \\
\hline
\end{tabular}

Note: the number of cells before cultivation was $(4.12 \pm 0.09) \times 10^{6} / \mathrm{mL}$, the cultivation period was 2 days.

Discussion. The ability to hydrolyze phytic acid and phytates is proper to different representatives of the soil microbiota, in particular micromycetes and bacteria [5]. Among the bacterial microbiota, this property is most common in members of the genus Bacillus. For example, B. subtilis KPS-11 showed both extracellular and cell associated phytase enzyme activity [2], B. licheniformis ATCC 14580 
synthesized highly thermostable phytase [12], B. subtilis VTT E-68013 produced extracellular highly specific phytase [13]. According to the results of our studies, strain B. subtilis IMV B-7023 also used sodium phytate as a source of phosphorus nutrition and showed strong growth (Table 1). However, it is possible to conclude that $0.5 \mathrm{~g} / \mathrm{L}$ of phytate is insufficient in the culture medium, because at this concentration less bacterial cells grew compared to media with 1.0 and $2.0 \mathrm{~g} / \mathrm{L}$ of this substance. We observed the tendency to gradual decrease of $B$. subtilis IMV B-7023 phytase activity from first to fourth day of cultivation in medium with $0.5 \mathrm{~g} / \mathrm{L}$ sodium phytate, while phytase activity increased on the third day in media with 1.0 and $2.0 \mathrm{~g} / \mathrm{L}$ of this substance, which may indicate depletion in such conditions of phytate as a substrate. At the same time, the growth of $B$. subtilis IMV B-7023 was minor during cultivation in the medium with sodium phytate as the source of carbon and phosphorus nutrition (Table 2). This indicates a low level of phytate assimilation as a source of carbon nutrition by these bacteria.

It should be noted that B. subtilis IMV B-7023 phytase activity was lower during cultivating in medium with sodium phytate as a source of phosphorus nutrition, than in medium with inorganic phosphates. The obtained results may be due to phytate hydrolysis by widespecific phosphatases, which, as shown in [14], are synthesized by $B$. subtilis IMV B-7023 actively. Higher rates of phytase activity obtained on the first and third days of bacterial cultivation may indicate the expression of phosphatases genes only in the period required for maximum bacterial development in the absence of these proteins in the media, as it was observed for B. licheniformis [15]. At the same time, B. subtilis IMV B-7023 phytase activity during cultivation in medium with sodium phytate as carbon and phosphorus source was similar $(2.0 \mathrm{~g} / \mathrm{L}$ phytate $)$ or higher ( 0.5 and $1.0 \mathrm{~g} / \mathrm{L}$ phytate) from this activity during bacterial cultivation in the medium with inorganic phosphates. This may indicate the synthesis of a larger number of specific phosphatases (phytases) in bacterial cells at the presence in the medium of only phytate as a substrate.

Thus, B. subtilis IMV B-7023 strain is characterized by growth on nutrient medium with sodium phytate and phytase activity. Because these are soil microorganisms used as the component of the "Azogran" complex bacterial preparation for plant growing, the ability to hydrolyze and assimilate phytate is important for functioning of this strain in the rhizosphere. The obtained results extend the understanding of B. subtilis IMV B-7023 influence on phosphorus nutrition and development of plants.

\section{POCTOBA TA ФITA3HA АКТИВНОСТI ВACILLUS SUBTILIS ІМВ В-7023 ЗА КУЛЬТИВУВАННЯ 3 ФITАТОМ НАТРІЮ}

\section{Н.В.Чуйко, А.Ю. Чоботарьов, І.К. Курдиш}

\author{
Інститут мікробіології і вірусології \\ ім. Д.К. Заболотного НАН Украӥни, \\ вул. Академіка Заболотного, 154, \\ Київ, 03143, Україна

\section{Резюме}

Бактерії роду Bacillus відомі здатністю солюбілізувати фосфор з важкорозчинних неорганічних фосфатів та мінералізувати органічні сполуки фосфору. Фітати становлять до $60-80$ \% від загального фосфору в рослинах та до 50 \% від органічного фосфору грунтів. В той же час фосфор фітатів $\mathrm{\epsilon}$ недоступним для рослин, а дефіцит доступного фосфору є однією з основних проблем сільськогосподарського виробництва. Представники роду Bacillus можуть синтезувати фосфатази як широкого спектру дії, так і вузькоспецифічні фітази, які каталізують гідроліз фітатів. Тому метою даної роботи було дослідження ростової та фітазної активності бактерій Bacillus subtilis IMB B-7023, які $є$ компонентом комплексного бактеріального препарату для рослинництва Азогран. Методи. Ростову активність бактерій досліджували культуральними методами, фітазну активність - шляхом вимірювання кількості фосфату, який вивільнявся з фітату натрію в ході ферментативної реакції. Результати. Показано, що B. subtilis IMB B-7023 засвоювали фітат в якості джерела фосфорного живлення за культивування на середовищах 3 $0,5,1,0$ і 2,0 г/л фітату натрію. Найвищу ростову активність цих бактерій спостерігали через дві доби культивування в середовищі з 1,0 г/л фітату (ї кількість становила $(3,91 \pm 0,32) \times 10^{9} \mathrm{KУО/мл).}$ В той же час $B$. subtilis IMB В-7023 продемонструвала низький рівень асиміляції фітату як джерела вуглецевого живлення. Так, за вмісту в поживному середовищі 0,5-2,0 г/л фітату та відсутності іншого джерела вуглецю через дві доби культивування кількість бактерій зросла $3(4,12 \pm 0,09) \times 10^{6}$ КУО/мл до $(1,07 \pm 0,07-3,11 \pm 0,51) \times 10^{7} \mathrm{KУО/мл.}$ Встановлено, що B. subtilis IMB В-7023 властива фітазна активність, яка була найвищою на першу 
добу їх культивування в середовищі з неорганіч-

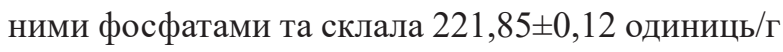
білка. Слід зазначити, що фітазна активність B. subtilis IMB B-7023 була нижчою за умови їх культивування в середовищі з фітатом натрію як джерелом фосфорного живлення, ніж у середовищі з неорганічними фосфатами. Отриманий факт може бути обумовлений гідролізом фітату широкоспецифічними фосфатазами, які, як відомо 3 попередніх досліджень, активно синтезуються даним штамом бацил. Вищі показники фітазної активності, отримані на середовищах з фітатом натрію як джерелом фосфорного живлення, на першу та третю добу культивування бактерій порівняно $з$ другою та четвертою можуть вказувати на експресію генів фосфатаз широкого та вузького спектру дії лише в потрібний для максимального бактеріального розвитку період за недостатньої кількості цих білків у середовищі. В той же час фітазна активність B. subtilis IMB В-7023 після дводобового культивування на середовищах з 0,5 i

1. Rodríguez H, Fraga R. Phosphate solubilizing bacteria and their role in plant growth promotion. Biotechnol Adv. 1999; 17(4-5):319-39.

2. Hanif MK, Hameed S, Imran A, Naqqash T, Shahid M, Van Elsas JD. Isolation and characterization of a $\beta$-propeller gene containing phosphobacterium Bacillus subtilis strain KPS-11 for growth promotion of potato (Solanum tuberosum L.). Front Microbiol. 2015; 6:583.

3. Yu P, Chen Y. Purification and characterization of a novel neutral and heat-tolerant phytase from a newly isolated strain Bacillus nealsonii ZJ0702. BMC Biotechnol. 2013; 13:78.

4. Jorquera M, Martínez O, Maruyama F, Marschner P, de la Luz Mora M. Current and future biotechnological applications of bacterial phytases and phytase-producing bacteria. Microbes Environ. 2008; 23(3): 182-91.

5. Fathallh Eida M, Nagaoka T, Wasaki J, Kouno K. Phytate degradation by fungi and bacteria that inhabit sawdust and coffee residue composts. Microbes Environ. 2013; 28(1):71-80.

6. Unno Y, Shinano T. Metagenomic analysis of the rhizosphere soil microbiome with respect to phytic acid utilization. Microbes Environ. 2013; 28(1):120-7.

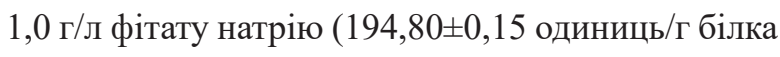

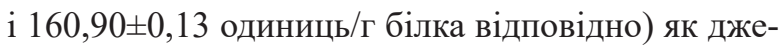
рела вуглецю та фосфору була вищою від їі показника в середовищі з неорганічними фосфатами $(137,79 \pm 0,10$ одиниць/г білка). Це може свідчити про синтез в бактеріальних клітинах за наявності в середовищі лише фітату в якості субстрату більшої кількості саме специфічних фосфатаз - фітаз. Висновки. Штаму B. subtilis IMB В-7023 властивий ріст на живильному середовищі з фітатом натрію та фітазна активність. Оскільки це грунтові мікроорганізми, що використовуються як компонент бактеріального добрива Азогран для рослинництва, здатність гідролізувати і засвоювати фітат $\epsilon$ важливою для їх функціонування в ризосфері. Отримані результати досліджень розширюють розуміння впливу B. subtilis IMB В-7023 на фосфорне живлення та розвиток рослин.

Ключові слова: Bacillus subtilis IMB B-7023, фiтат, ростова активність, фітазна активність.

7. Roi AA, Reva ON, Kurdish IK, et al. Biological Properties of the Phosphorus-Mobilizing Bacillus subtilis Strain IMV V-7023. Applied Biochemistry and Microbiology. 2004; 40:476-481.

8. Patent of Ukraine №54923 A. [Strain of bacteria Bacillus subtilis for bacterial fertilizer obtaining for plant growing]. Kurdish IK, Roy AO. Published in 2003. Bul. №3. Ukrainian.

9. Rocky-Salimi K, Hashemi M, Safari M, Mousivand M. A novel phytase characterized by thermostability and high $\mathrm{pH}$ tolerance from rice phyllosphere isolated Bacillus subtilis B.S.46. J Adv Res. 2016; 7(3):381-90.

10. Singh NK, Joshi DK, Gupta RK. Isolation of Phytase Producing Bacteria and Optimization of Phytase Production Parameters, Jundishapur. J Microbiol. Online ahead of Print. 2013; 6(5):6419.

11. Lakin G.F. [Biometry]. Moskow:Vysshaia shkola; 1990. 352 p. Russian.

12. Mohamed Ali Borgi, Samira Boudebbouze, Héla Mkaouar, Emmanuelle Maguin, Moez Rhimi. Bacillus phytases: Current status and future prospects. Bioengineered. 2015; 6:233-236.

13. Kerovuo J, Lauraeus M, Nurminen P, Kalkkinen N, Apajalahti J. Isolation, characterization, 
molecular gene cloning, and sequencing of a novel phytase from Bacillus subtilis. Appl Environ Microbiol. 1998; 64(6):2079-85.

14. Bulavenko LV, Kurdysh IK. [Phosphatase activity of Bacillus subtilis IMV B-7023]. Mikrobiol Z. 2005; 67(4):21-7. Ukrainian.
15. Trung NT, Hung NM, Thuan NH, et al. An auto-inducible phosphate-controlled expression system of Bacillus licheniformis. BMC Biotechnol. 2019; 19:3.

Received 23.06.2021 